\title{
Lithistid spicules in the sediments of the Turonian Variegated Shale in the Silesian Nappe, Polish Outer Carpathians
}

\author{
Szymon Okoński ${ }^{1}$, Zbigniew Górny ${ }^{2}$, Marta Bąk ${ }^{3}$, Krzysztof Bąk ${ }^{1}$ \\ ${ }^{1}$ Institute of Geography, Pedagogical University of Cracow; \\ ul. Podchorażych 2, 30-084 Krakow, Poland; e-mail: sokonski@up.krakow.pl \\ ${ }^{2}$ Institute of Geological Sciences, Jagiellonian University; \\ ul. Oleandry2a,30-063 Krakow, Poland; e-mail: mzbigniew.gorny@uj.edu.pl \\ ${ }^{3}$ AGH University of Science and Technology, Faculty of Geology, Geophysics and Environmental Protection; \\ al.Mickiewicza 30,30-059Krakow,Poland;e-mail:martabak@agh.edu.pl,msgbak@cyf-kr.edu.pl
}

(C) 2014 Authors. This is an open access publication, which can be used, distributed and reproduced in any medium according to the Creative Commons CC-BY 4.0 License requiring that the original work has been properly cited.

\begin{abstract}
Turbiditic silty and sandy intercalations in the Turonian Variegated Shale from the Silesian Nappe (Polish Outer Carpathians) contain numerous sponge spicules among siliciclastic fine-grained particles. The highest amount of spicule admixture is nearly $50 \%$. In such layers, they create spiculitic sublitharenite microfacies. These sponge spicules contain forms belonging mostly to the Lithistida group ( $97 \%$ of morphotypes), with a small admixture of spicules from the Hexactinellidae group. Tetraclones with a high content of different types of triaenes dominate among desmas, what indicates the dominance of sponges from subfamily Tetracladina. The preservation state of spicules is generally poor. The Variegated Shale deposits that contain the sponge spicules were accumulated in a deep sea basin, below the calcium compensation depth. Most probably, the spicules were derived from loose material accumulated earlier in various parts of the basin slopes, from which they were exhumed and again redeposited by turbidity currents during the Turonian times.
\end{abstract}

Keywords: sponge spicules, Lithistida, Turonian, Variegated Shale, Silesian Nappe, Outer Carpathians

\section{INTRODUCTION}

Lithistid sponges first appeared as framework builders in the Early Ordovician, and rapidly evolved, adapting to shallow-water, agitated environments (Wiedenmayer 1980). In the Late Carboniferous and Permian, lithistid sponges reached their peak in diversification. The second major period of siliceous sponges' radiation and diversification was the Late Jurassic, when sponge-bearing facies became widespread along the northern margin of the Western Tethys (Wiedenmayer 1980). The Early through Mid-Cretaceous times represent another period of relatively diverse sponge faunas' growth within the epicontinental seas. Sponge community with relatively diverse lithistids was common especially within the glauconitic and chalk facies of this age in the North and Northwestern Europe (Nestler 1961, Reid 1962, Wiedenmayer 1980, Gasse et al. 1991, Kauffmann et al. 2000).

The Mid-Cretaceous (Albian-Cenomanian) was a period of accumulation of spicule-bearing deposits also in the deep basins of the Outer Carpathians, spreading-out along the southern edge of the West European Platform. These 
are fine-grained turbidities consisting of detrital material mixed with biogenic particles, which are predominantly siliceous spicules of lithistids. The previous concept of the deposition time of spicule-bearing deep-water sediments was that it terminated during the Late Cenomanian, before the oceanic anoxic event (OAE2). In this paper, we present and discuss new data about the occurrence of sponge spicules in the Turonian deepwater facies (after the OAE2), ending the main period of spicule-bearing sedimentation in the Silesian Basin (Polish Outer Carpathians).

\section{GEOLOGICAL SETTING}

The Outer Carpathians (Fig. 1A, B) comprises several nappes folded and overthrust mainly during the Middle and Late Miocene times (e.g. Książkiewicz 1975, 1977, Oszczypko 2006) as a result of oblique convergence between the Eurasian Plate and Alcapa (e.g. Golonka et al. 2000, Csontos \& Vörös 2004). The Silesian Nappe belongs now to the outer group of nappes and forms a wide belt along the margin of the Magura Nappe within the Czech, Polish and Ukrainian territories (Książkiewicz 1977).

During the Cretaceous, the Outer Carpathian area consisted of several deep longitudinal basins, separated by shallow (submarine) or emergent ridges. The deposits of the Silesian Nappe have been deposited within the basin, restricted to the south by the exotic Silesian ridge and to the north by the southern margin of the West European Platform (to the west) and by the submarine Subsilesian ridge (to the east) (Książkiewicz 1962). In the Silesian Basin, the sedimentation begun during the Late Jurassic times (e.g. Książkiewicz 1956, 1977, Oszczypko 2004).

Sedimentation of spicule-bearing turbidites (upper part of the Middle Lgota Beds; Fig. 2) started during the Albian (Unrug 1959, 1977, Alexandrowicz 1973). These sediments are composed of centimetre-thick beds (up to $25 \mathrm{~cm}$ thick) of fine- to medium-grained, dark-grey and black greywakes, siliceous shales and biomicrites, partly silicified, in packages up to $20 \mathrm{~cm}$ thick. Parallel lamination predominate, with laminas of $0.1-0.4 \mathrm{~mm}$ thick, built of alternating quartz, black mineral grains, and flats of organic matter.
The main body of the spicule-bearing deposits is represented by the Mikuszowice Cherts (Upper Lgota Beds; Fig. 2), Middle-Late Cenomanian in age (Sujkowski 1933, Książkiewicz 1936, M. Bąk et al. 2005, 2011, 2013). These deposits are composed of centimetre-thick turbidites, which are finegrained siliciclastics such as greywackes, mudstones and siltstones, with biogenic admixture, and also calcarenites to calcisiltites, usually silicified. The most distinguishing feature of these deposits, visible only in thin sections, is a high content of siliceous sponge spicules. Other commonly present biogenic particles are planktonic and benthic calcareous foraminifers, and radiolarians.

The sedimentation rate of the spicule-bearing turbidites decreased upward section, as documented in the Barnasiówka Radiolarian Shale Formation (14.5 m thick; Fig. 2; K. Bąk et al. 2001, K. Bąk 2007a). This unit includes the uppermost Cenomanian organic-rich facies of the oceanic anoxic event (OAE2; K. Bąk 2007a). It is followed by the Turonian hemipelagic non-calcareous Variegated Shale (Fig. 2), where the delivery of spicules finally terminated. These deposits are mainly non-calcareous, red and green claystones, with rare silty and sandy turbidite intercalations. In the Silesian Nappe, the Variegated Shale is covered by a succession of glauconite-rich turbidites of the Godula Beds (not studied here) up to $600 \mathrm{~m}$ in the surrounding area (Fig. 1B; Słomka 1995).

\section{Geological sections}

Sponge spicules have been studied in two sections, located in the western part of the Silesian Nappe (Polish Outer Carpathians): (1) at the Barnasiówka-Jasienica quarry and (2) in the right tributary of the Zasanka stream at Trzemeśnia village (Fig. 1A, B).

The Barnasiówka-Jasienica quarry section (active quarry during field studies in 2011-2012) is located in the vicinity of the Bysina and Jasienica villages, $5 \mathrm{~km}$ west of Myślenice town, about $30 \mathrm{~km}$ south of Kraków (Fig. 1A, B). In this quarry, the succession of the Variegated Shale (10.5 m thick) occurs in its northern part, where it is underlain by the Barnasiówka Radiolarian 
Shale Formation (14.5 m thick), the Mikuszowice Cherts (35 m thick) and the upper part of the Middle Lgota Beds (about 20 m thick; Figs 1C, 2).
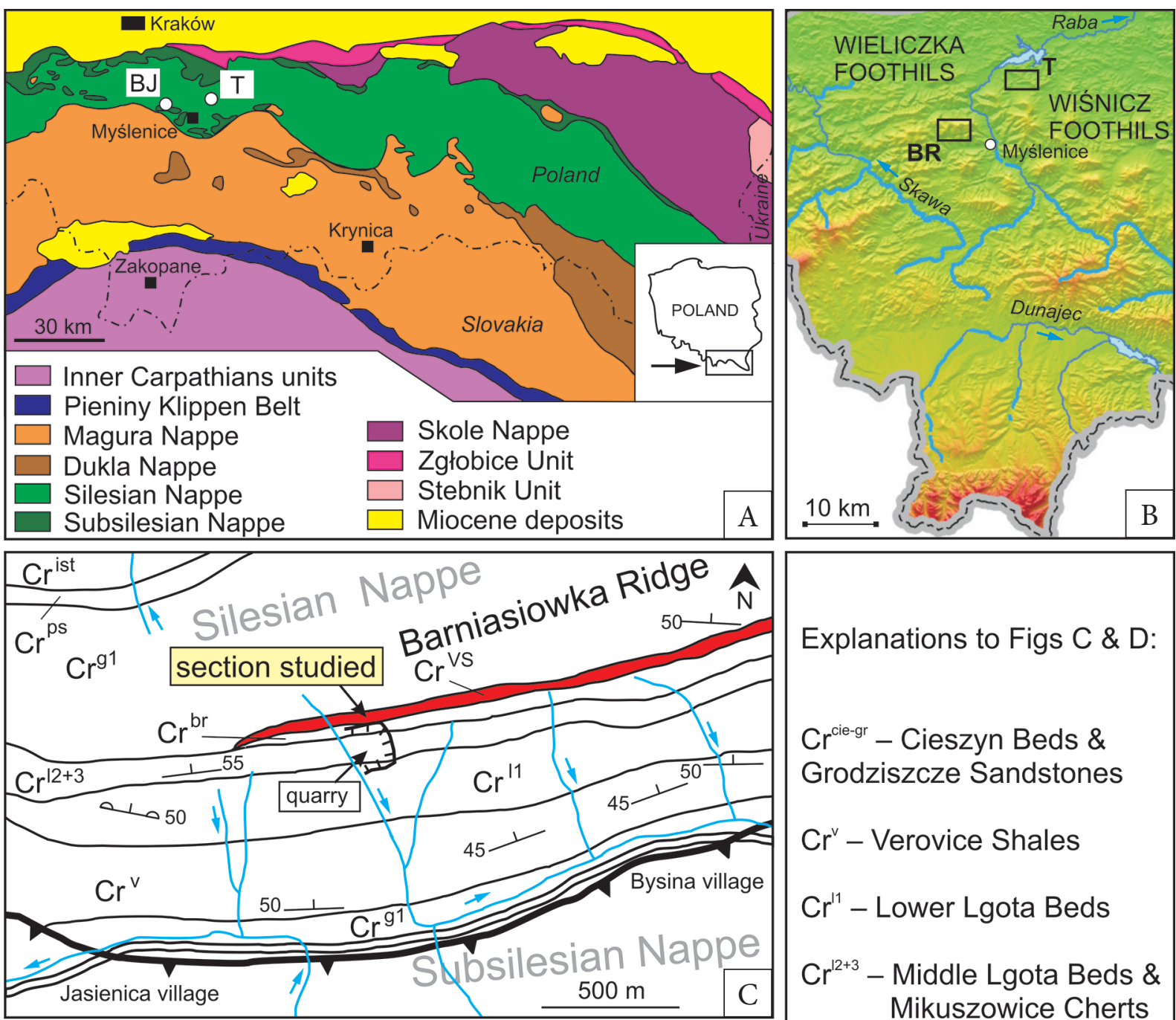

Explanations to Figs C \& D:

$C r^{\text {cie-gr }}-$ Cieszyn Beds \& Grodziszcze Sandstones

$\mathrm{Cr}^{v}$ - Verovice Shales

$\mathrm{Cr}^{11}$ - Lower Lgota Beds

$\mathrm{Cr}^{12+3}$ - Middle Lgota Beds \& Mikuszowice Cherts

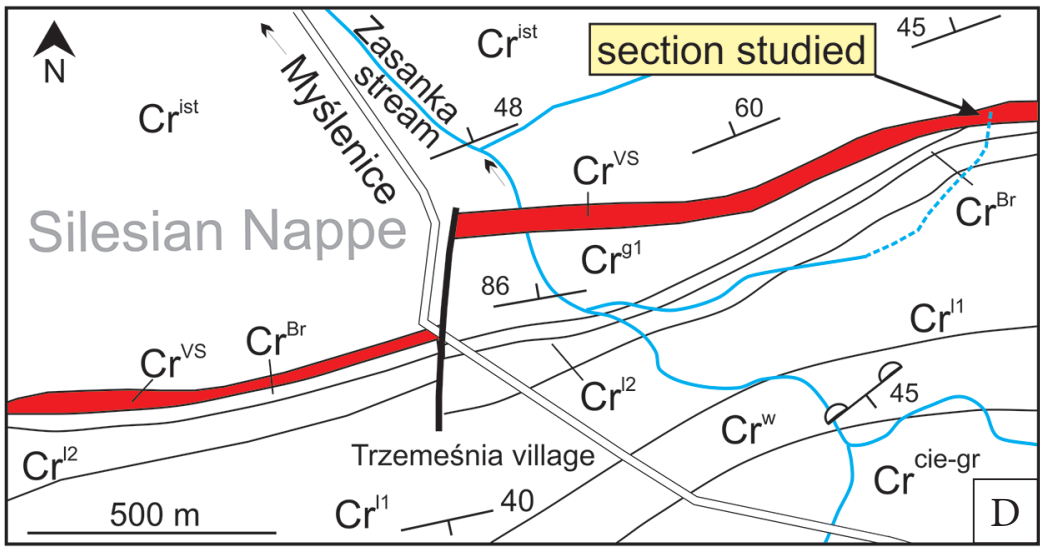

$\mathrm{Cr}^{\mathrm{Br}}$ - Barnasiówka Radiolarian Shale Fm.

\section{$\mathrm{Cr}^{\mathrm{vs}}$ - Variegated Shale}

$\mathrm{Cr}^{\mathrm{g}}$ - Lower Godula Beds

$\mathrm{Cr}^{\text {ist }}$ - Istebna Sandstones

Fig. 1. A) geological sketch-map of the Polish Carpathians (after Żytko 1999) with location of the studied sections (BJ - Barnasiówka-Jasienica quarry, T - Trzemeśnia village); B) physical map of the southern Poland with location of the Barnasiówka ridge (BR - Wieliczka Foothils) and Trzemeśnia surroundings (T - Wiśnicz Foothils); map after Bryndal (2011); C) geological map of the studied area around the Barnasiówka ridge (Outer Carpathians, Silesian Nappe) after Burtan (1964a), Burtan \& Szymakowska (1964), and K. Bąk et al. (2001, slightly modified); D) geological map of the studied area around Trzemeśnia village (Outer Carpathians; Silesian Nappe) after Burtan $(1964 b, c)$ and K. Bąk et al. (2001, slightly modified) 


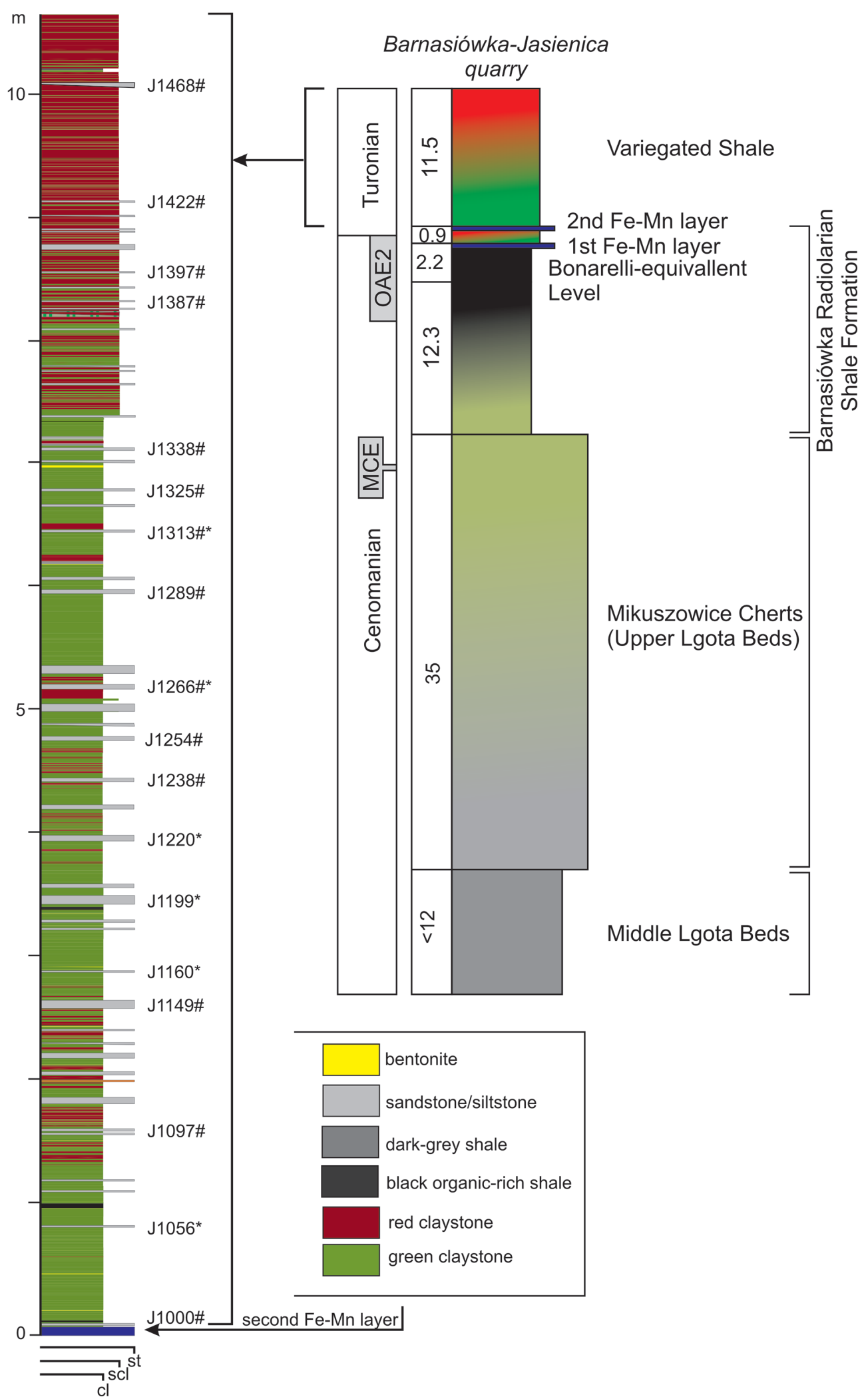

Fig. 2. Detailed lithology of the Turonian Variegated Shale in the Barnasiówka-Jasienica quarry (after Okoński 2012) against the main lithostratigraphic units (Cenomanian-Turonian) outcropped in the quarry; based on field studies during 2011-2012. Lithostratigraphy and datum events based on data by K. Bąk (2007a) and M. Bąk (2011). Samples for microfacies analyses are signed by \# symbol. Samples for micropalaeontological analyses are signed by ${ }^{*}$ symbol; cl-claystone, scl-silicified claystone, st - siltstone or sandstone 


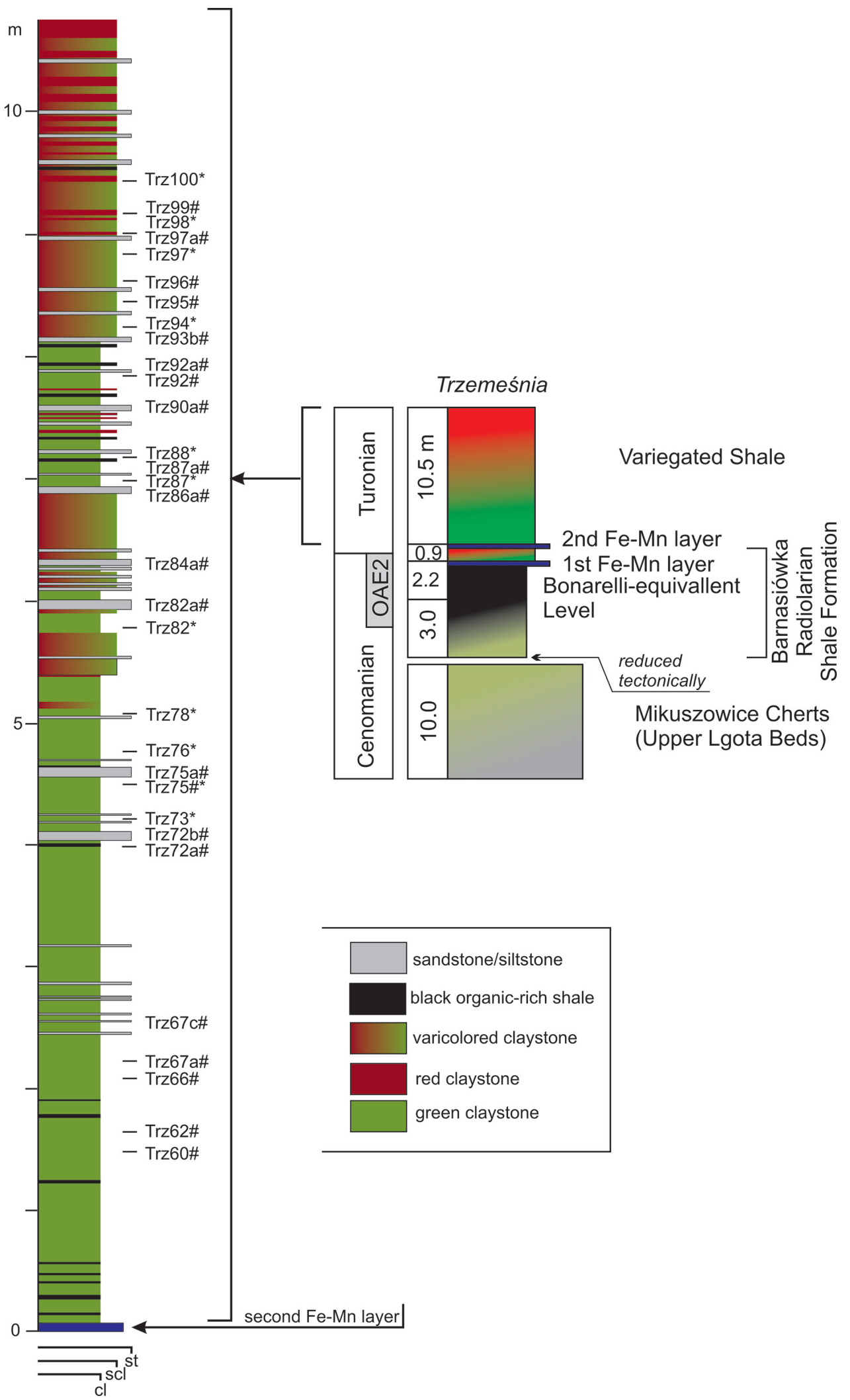

Fig. 3. Detailed lithology of the Turonian Variegated Shale in the Trzemeśnia section against the main lithostratigraphic units (Cenomanian-Turonian) outcropped in the surrounding area; based on K. Bak (2007a). Lithostratigraphy and datum events based on data by K. Bak (2007a) and M. Bąk (2011). Samples for microfacies analyses are signed by \# symbol. Samples for micropalaeontological analyses are signed by ${ }^{*}$ symbol; $\mathrm{cl}$-claystone, scl-silicified claystone, st - siltstone or sandstone 
The Trzemeśnia section is situated $10 \mathrm{~km}$ east of Myślenice in the Trzemeśnia village, near the mouth of a right short tributary of the Zasanka stream (Fig. 1A, B, D). In this section, the Variegated Shale (10.5 m thick) occurs in the topmost part of the creek. These sediments are underlain by the upper part of the Barnasiówka Radiolarian Shale Formation (BRSF; about $5 \mathrm{~m}$ thick; Figs 1D, 3). The BRSF is in tectonic contact with the Mikuszowice Cherts (about $10 \mathrm{~m}$ thick), which are also tectonically reduced in this locality.

The Variegated Shale in both studied sections is composed of predominantly non-calcareous green, red and varicolored claystones/mudstones with rare thin intercalations of siltstones and thin-bedded (up to $6 \mathrm{~cm}$ ) fine-grained sandy turbidites (Figs 2,3). The most common bioclasts visible in thin sections of the turbidite layers are radiolarians and spicules of sponges. They are present in claystone, siltstone, and sandstone, ranging between 1-50\%.

\section{Stratigraphy}

Green, red and varicolored siliceous claystones/ mudstones (Variegated Shale) lies on the uppermost Cenomanian organic-rich facies, interpreted as an equivalent of the Bonarelli Level (K. Bąk 2007a-d), known from the Northern Apennines and other Tethyan regions. The organic-rich horizon, about 2.2 $\mathrm{m}$ thick, visible in both studied sections (Figs 2, 3), represents sediments of the oceanic anoxic event (OAE2), as was documented using stable carbon isotope stratigraphy by K. Bąk $(2006,2007 \mathrm{a}-\mathrm{c})$. This horizon is overlain by the first ferromanganese layer (about $10 \mathrm{~cm}$ thick), a chronohorizon in the Polish Outer Carpathians (K. Bąk 2007d), in which the first red siliceous claystone layer occurs. According to K. Bąk (2007a, d), a correlation of the organic carbon curves from the Outer Carpathian sections with the high resolution data from the Pueblo (USA; Sageman et al. 2006) shows that the base of the Variegated Shale lies in the uppermost Cenomanian, near the Cenomanian-Turonian boundary. This boundary is marked in $0.5-0.9 \mathrm{~m}$ thick interval between the base of the first Fe-Mn layer (directly overlying the organic-rich facies) and the base of the first organic-rich shale, which directly underlies the second Fe-Mn layer (for details see: K. Bąk 2007a-d). Consequently, excluding the $0.9 \mathrm{~m}$ thick interval between two ferromanganese layers, the remaining part of the studied Variegated Shale corresponds to the Turonian. More precise determination of the age of the Variegated Shale is impossible due to a lack of diagnostic for age micro- and macrofossils. The previous stratigraphic studies from the Silesian Nappe, based mainly on Radiolaria and agglutinated Foraminifera (e.g. Bieda et al. 1963, M. Bąk 2000, 2011, K. Bąk et al. 2001), did not allow the division of the Turonian stage into stratigraphic zones.

\section{METHODS}

A total of 18 samples from a $10.5 \mathrm{~m}$ thick section of the Variegated Shale in the Barnasiówka-Jasienica quarry and 31 samples from a similar section in Trzemeśnia were used in this study. Samples were collected every $10-50 \mathrm{~cm}$ from mudstone/siltstone and sandstone layers. Sponge spicules were extracted from pieces of about $200 \mathrm{~g}$ weight, which were treated by $3-5 \%$ hydrofluoric acid. Residues (1-3 g) were dried, weighed and washed through sieves with mesh diameters of $500-63 \mu \mathrm{m}$. The microfossils and microfacies were additionally determined in thin sections of the rocks (for samples location see: Figs 2, 3).

The microfacies analysis was focused on the recognition of the mineral and biogenic components of the turbidite layers in the Variegated Shale and also of the type of cement. The classifications after Folk (1974) and Pettijohn et al. (1972) were used for siliciclastic rocks, and classifications after Folk $(1959,1962)$ were used for carbonate rocks. Photographs of microfauna and microfacies were made using the stereoscopic microscope by Nikon SMZ1500 with digital camera. Microfaunal slides and thin sections are housed in the Geology Department of the Institute of Geography, Pedagogical University of Cracow.

\section{RESULTS}

\section{Microfacies with sponge spicules in the Variegated Shale}

The sandstone and siltstone layers of the Turonian Variegated Shale contain quartz, glauconite grains, mica flakes, and biogenic clasts which are sponge spicules and radiolarian skeletons. The highest amount of biogenic admixture is 50\%. The lithological content and diversity of these formations were mainly controlled by turbidity currents which dominated sedimentation in the Silesian 
basin at that time. Diversity of clastic components and their volume in relation to matrix allowed for a determination of various lithofacies within these deposits (Figs 4-8). Usually, a single turbidite layer represents a sequence of microfacies, resulting from the segregation of particles by the flow and gravity settling. A single depositional event may include detrital grains such as quartz and lithic grains, usually forming a sequence of microfacies as: sublitharenite passing upwards to sublitharenite with increasing content of sponge spicules, which passes into microfacies containing more clay and/or micrite/sparite with increasing content of radiolarians. These sequences finally pass to deep-water hemipelagites and pelagites without sponge spicules.
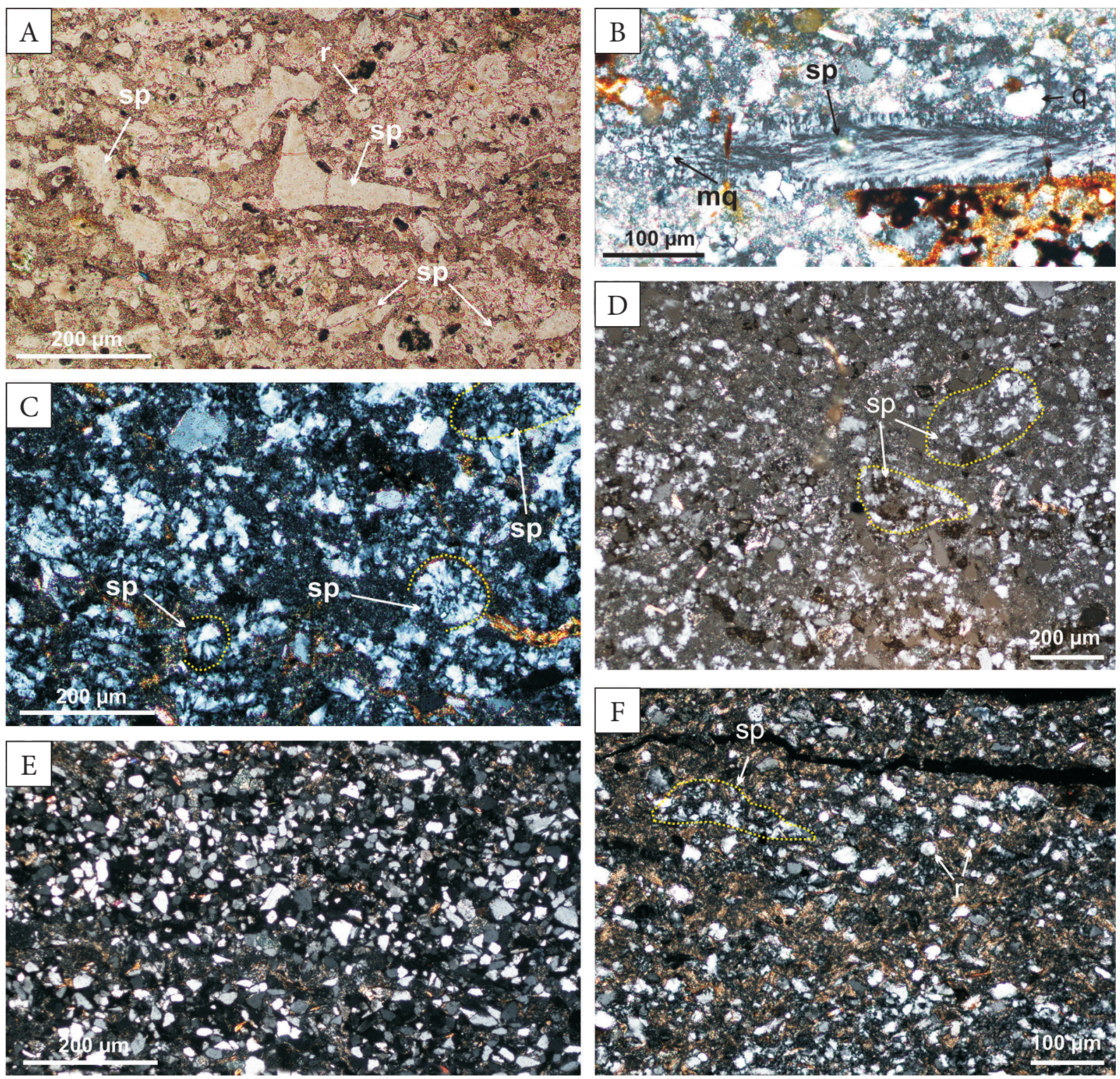

Fig. 4. Microfacies of turbiditic layers containing sponge spicules from the Turonian Variegated Shale in the BarnasiówkaJasienica quarry: A) sublitharenite enriched in sponge spicules (sp) containing rare radiolarians ( $r$ ), sample J1000, plane-polarized light; B) close-up view of quartz-glauconitic fine arenite with rare sponge spicules (sp) filled with microquartz crystals (mq), sample J1000, cross-polarized light; C) sublitharenite enriched in sponge spicules (sp) showing different orientation of spicules, sample J1097, cross-polarized light; D) general view of sublitharenite enriched in sponge spicules (sp), sample J1266, cross-polarized light; E) general view of quartz fine arenite, sample J1325, cross-polarized light; F) spiculitic fine sublitharenite with sponge spicules (sp) and voids after radiolarian skeletons $(r)$ which are filled with isopachous rims or pseudobotryoidal chalcedony cement, sample J1325, cross-polarized light 

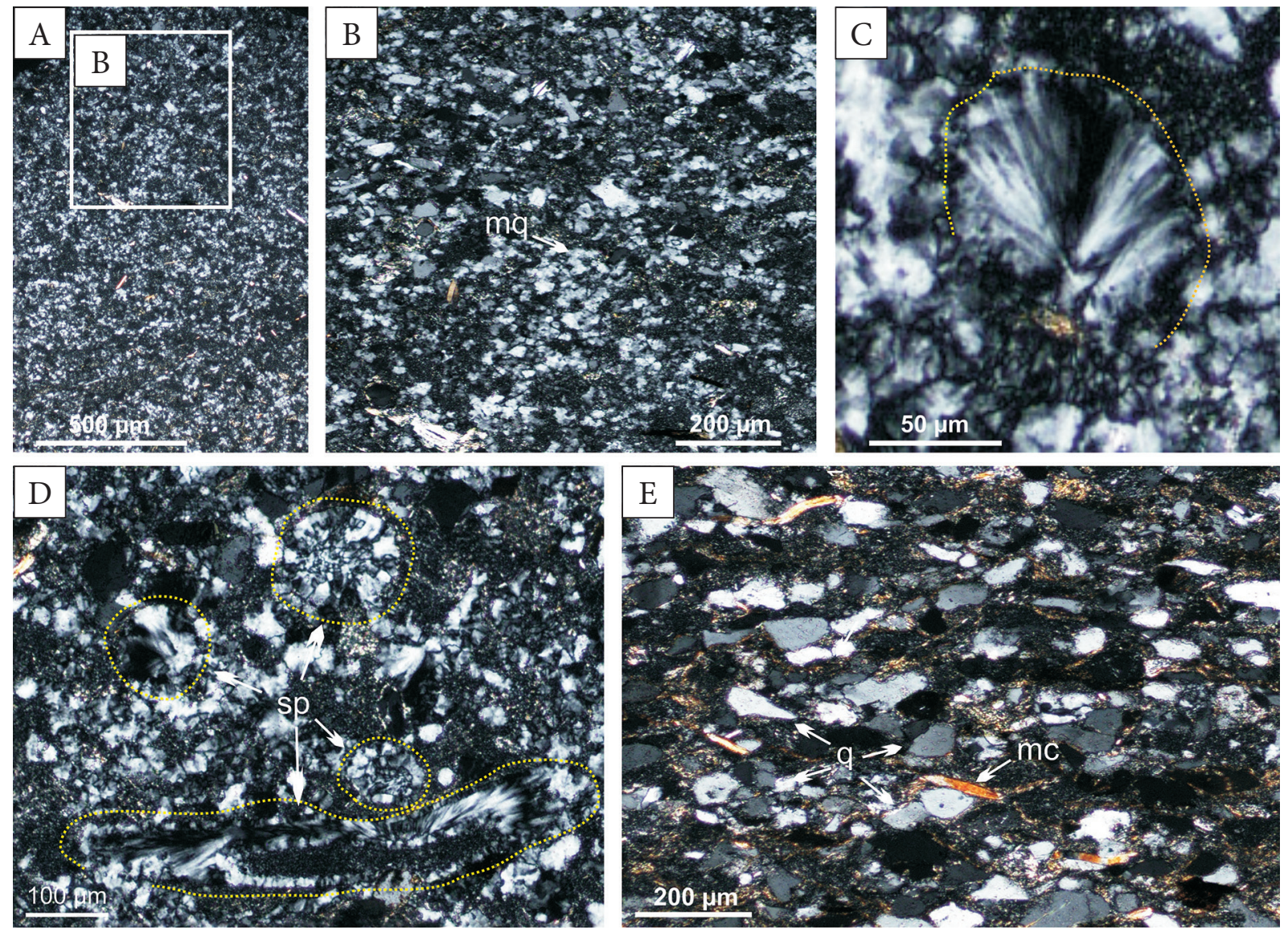

Fig. 5. Microfacies of turbiditic layer containing sponge spicules from the Turonian Variegated Shale in the BarnasiówkaJasienica quarry, sample J1149, cross-polarized light: A) quartz fine arenite; B) close-up view showing microquartz cluster $(\mathrm{mq})$ which may be a remnant of recrystallized spicules of sponge; C) cross-section of sponge spicule filled with botryoidal chalcedony cement; D) close-up view of sponge spicule cross-sections (sp) showing different stages of recrystallization from chalcedony cement to micro- and mega-quartz; E) general view of siltstone showing quartz grains and mica flakes surrounding by sparite

Seven types of microfacies have been distinguished in the Turonian Variegated Shale succession. There are: (1) quartz fine arenite and siltstone, (2) quartz-glauconitic fine arenite and siltstone, (3) sublitharenite enriched in sponge spicules, (4) spiculitic fine sublitharenite, (5) radiolarian-spiculitic packed biomicrite, (6) radiolarian sparse biomicrite, and (7) pellet sparse biomicrite.

Quartz fine arenite and siltstone (Figs 4E, 5A, $6 \mathrm{~A})$ are fine- to medium-grained rocks, composed of quartz (up to $85 \%$ ), carbonate, mica, and lithic grains, with calcitic matrix or cement. They include usually less than $1 \%$ of biogenic components such as sponge spicules (Fig. 5B-D). Radiolarians are not visible in thin sections. They are also rarely present in a loose residuum after the chemical disintegration of a rock sample.
Quartz-glauconitic fine arenite and siltstone (Figs 4B, 6B) are equivalents of quartz fine arenite and siltstone, but these microfacies contain much more grains of glauconite, with the highest abundance, up to $40 \%$, in some layers.

Sublitharenite enriched in sponge spicules (Figs 4A-E, 5C, D, 7A, B) contains less than 15\% microquartz matrix, and the framework consists of fine-grained quartz. Biogenic grains are dominated by sponge spicules and small admixture (1-3\%) of radiolarian tests.

Spiculitic fine sublitharenite (Fig. 8A) contains fine quartz grains with an admixture of biogenic particles which are mostly sponge spicules, associated with radiolarians. The content of sponge spicules is up to $50 \%$. They are present as recrystallized microquartz. The average content of 
radiolarians range between $0 \%$ and $20 \%$ of sandsize grains. Radiolarian skeletons are moderately to poorly preserved and recrystallized. Intraparticle porosity or voids after radiolarian skeletons are filled with isopachous rims or pseudobotryoidal chalcedony cement.
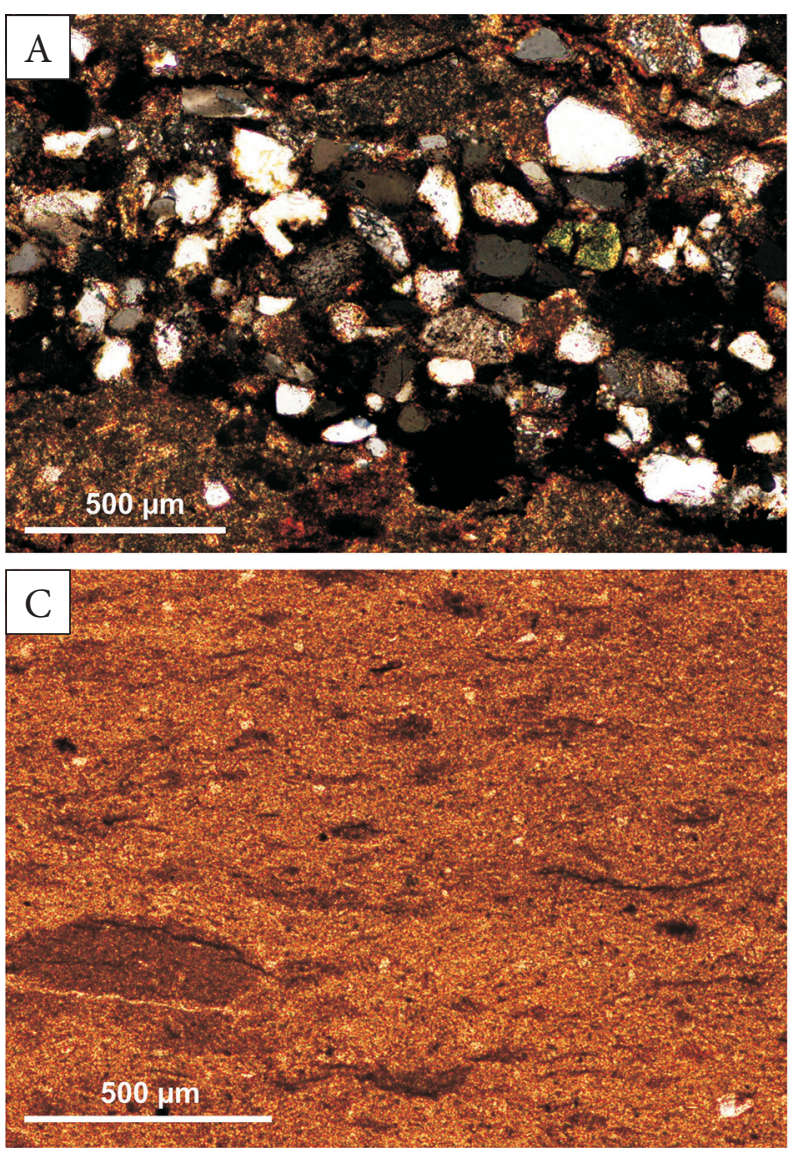

Radiolarian-spiculiticpacked biomicrite(Fig.7C, D) usually passes to radiolarian sparse biomicrite (Fig. 7E, F), where radiolarians predominate as particles of grain skeleton surrounding by more clayey matrix. Radiolarians make up to $60 \%$ of this microfacies.

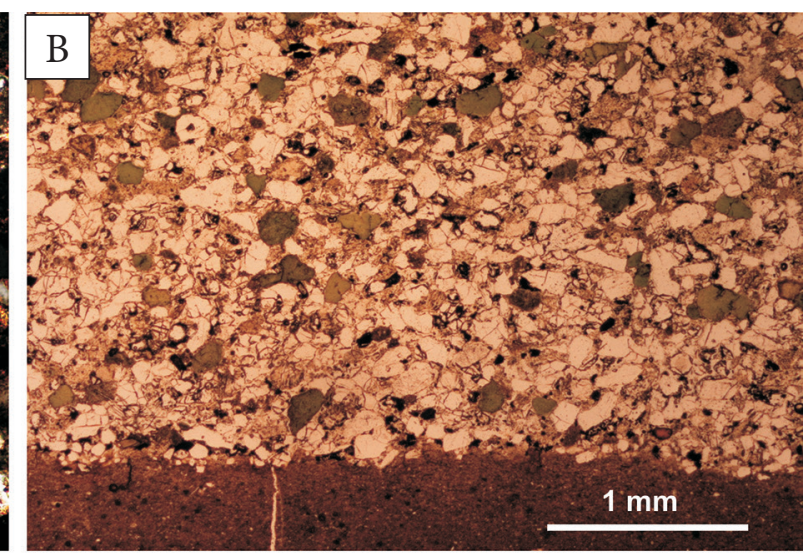

Fig. 6. Microfacies of the Turonian Variegated Shale in the Trzemeśnia section: A) close-up view of thin quartz fine arenite seam in red shale, sample Trz67a, cross-polarized light; B) one-millimeter thick layer of quartz-glauconitic fine arenite gradually passing into siltstone, its lower boundary with pellet sparse biomicrite is sharp, sample Trz67a, plane-polarized light; C), D) close-up view of the same part of thin section under plane-and cross-polarized light, showing pellet sparse biomicrite containing well-preserved pellets, sample Trz67c

Their dimensions range from less than $25-250 \mu \mathrm{m}$. Spicules of siliceous sponges belong toother biogenic components. Spicules located in clayey surroundings are set out from their usual parallel position because of compaction. This arrangement might be an effect of bioturbation, but it is interpreted here as resulting from more extensive cementation near clayey seams, which were a source of dissolved solids for cementation and subsequent silicification.

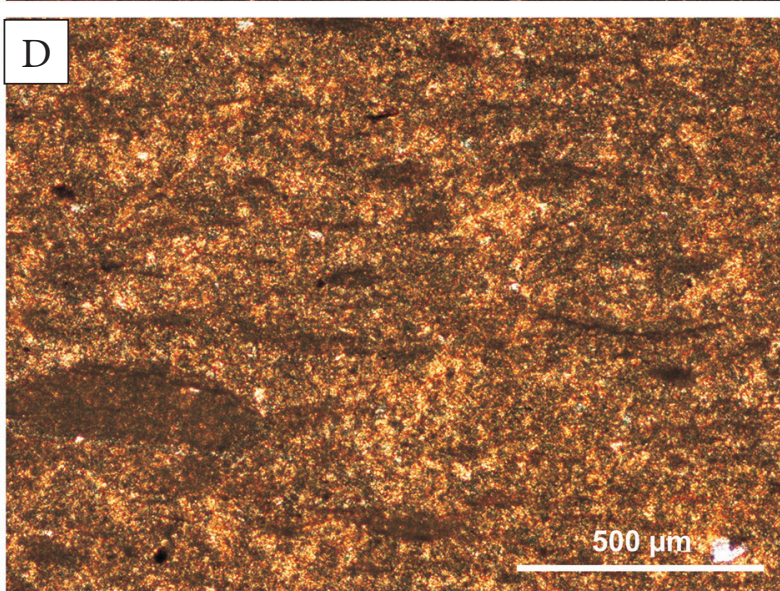


from $50 \mu \mathrm{m}$ to $250 \mu \mathrm{m}$. The pellets may comprise up to $70 \%$ of the rock, though their greater proportion cannot be excluded because partly disintegrated or strongly flattened pellets are difficult to recognize. Pellets sharply separated from the background are less common than disintegrated forms. Pellets differ in size and shape. They are regularly ellipsoidal to oval, some of them are slightly flattened; ellipsoidal forms predominate.
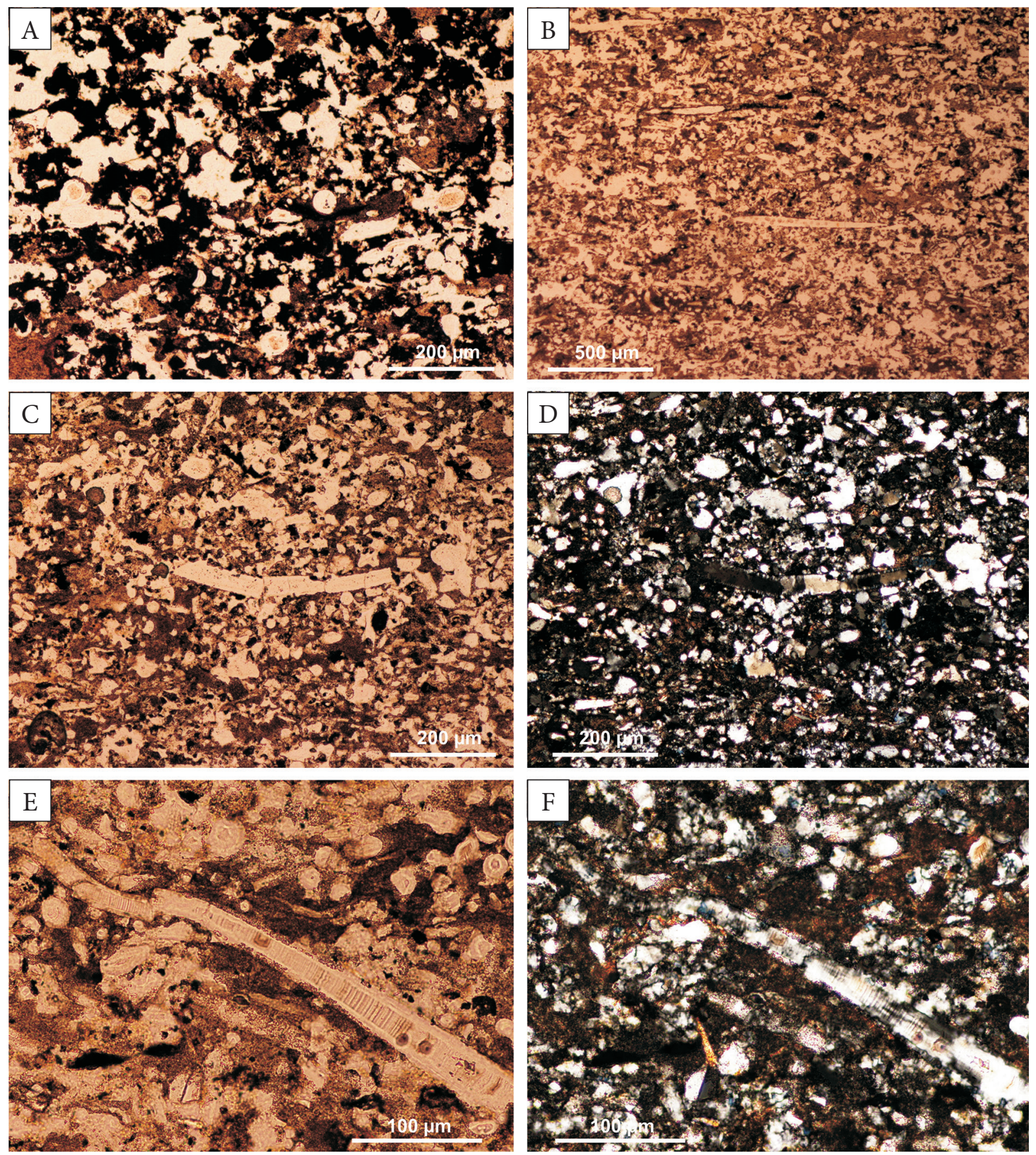

Fig. 7. Microfacies of turbiditic layers containing sponge spicules from the Turonian Variegated Shale in the Trzemeśnia section: A) sublitharenite enriched in sponge spicules; most of the spicules are strongly crushed, with traces of dissolution and later recrystallization, sample Trz72, plane-polarized light; B) spiculitic sublitharenite with parallel arrangement of sponge monaxones, sample Trz75a, plane-polarized light; C), D) general view of radiolarian-spiculitic packed biomicrite; view of the same part of thin section under plane- and cross-polarized light, sample Trz75a; E), F) close-up view of radiolarian-spiculitic packed biomicrite under plane- and cross-polarized light, showing that biogenic grains are surrounded by sparite, sample Trz75a 

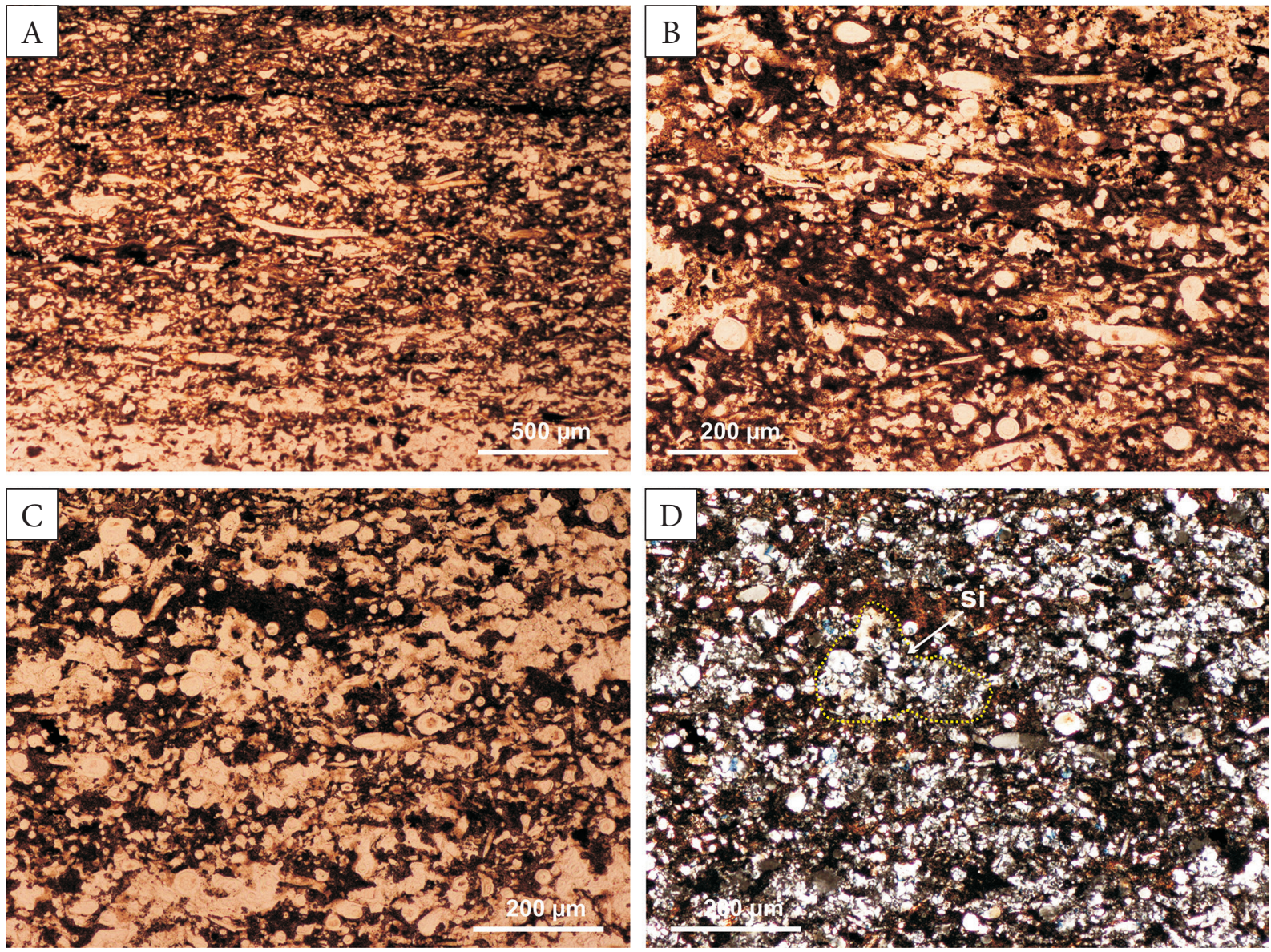

Fig. 8. Microfacies of turbiditic layers containing sponge spicules and radiolarians from the Turonian Variegated Shale in the Trzemeśnia section: A) general view of several seams of spiculitic sublitharenite passing upward into radiolarian sparse biomicrite, sample Trz87a, plane-polarized light; B) close-up of radiolarian-spiculitic sparse biomicrite, infilled voids after radiolarians which are present in more clayey part, sample Trz75a, plane polarized light; $C$ ), D) general view of radiolarian spiculitic sparse biomicrite under plane- and cross-polarized light; note area of silicification (si) which is visible around the sponge spicules within clay material, sample Trz87a

\section{Sponge spicules}

Spicules of sponges are present in the Variegated Shale within siltstone/mudstone and sandstone layers, which are usually less than $6 \mathrm{~cm}$ thick. They start to appear about 2-2.5 $\mathrm{m}$ above the organicrich facies of the OAE2 in the studied sections. In singular turbiditic layer, spicules are present only in redeposited sediments. They are most common in sand-fraction of the sediment and become absent in the uppermost interval of a Bouma sequence that is related to pelagic sediment.

The assemblages of isolated spicules contain mostly forms, which belong to the Lithistida group (97\% of morphotypes), with a small admixture of spicules belonging to the Hexactinellidae. The predominance of tetraclones among desmas, and the high-content of different types of triaenes
(Fig. 9), indicate the dominance of sponges from subfamily Tetracladina (sensu Zittel 1878 vide De Laubenfels 1955).

Three sponge spicule morphotypes dominate. These are triaenes, desmas and selenasters (Fig. 9). Spicules of Hexactinellidae (Fig. 9R) are very rare.

The total content of triaenes in the whole spicule assemblages is $59 \%$. Triaens are always fouraxis, and they can be classified into basic subtype according to Pisera (1997). The first distinguished subtype is represented by tetractines, which are caltrops or tetractines with one reduced arm. The second subtype comprises of spicules with one long axis and three, short axes bifurcating at one side of spicule. Dichotriaenes and prodichotriaenes predominate. 


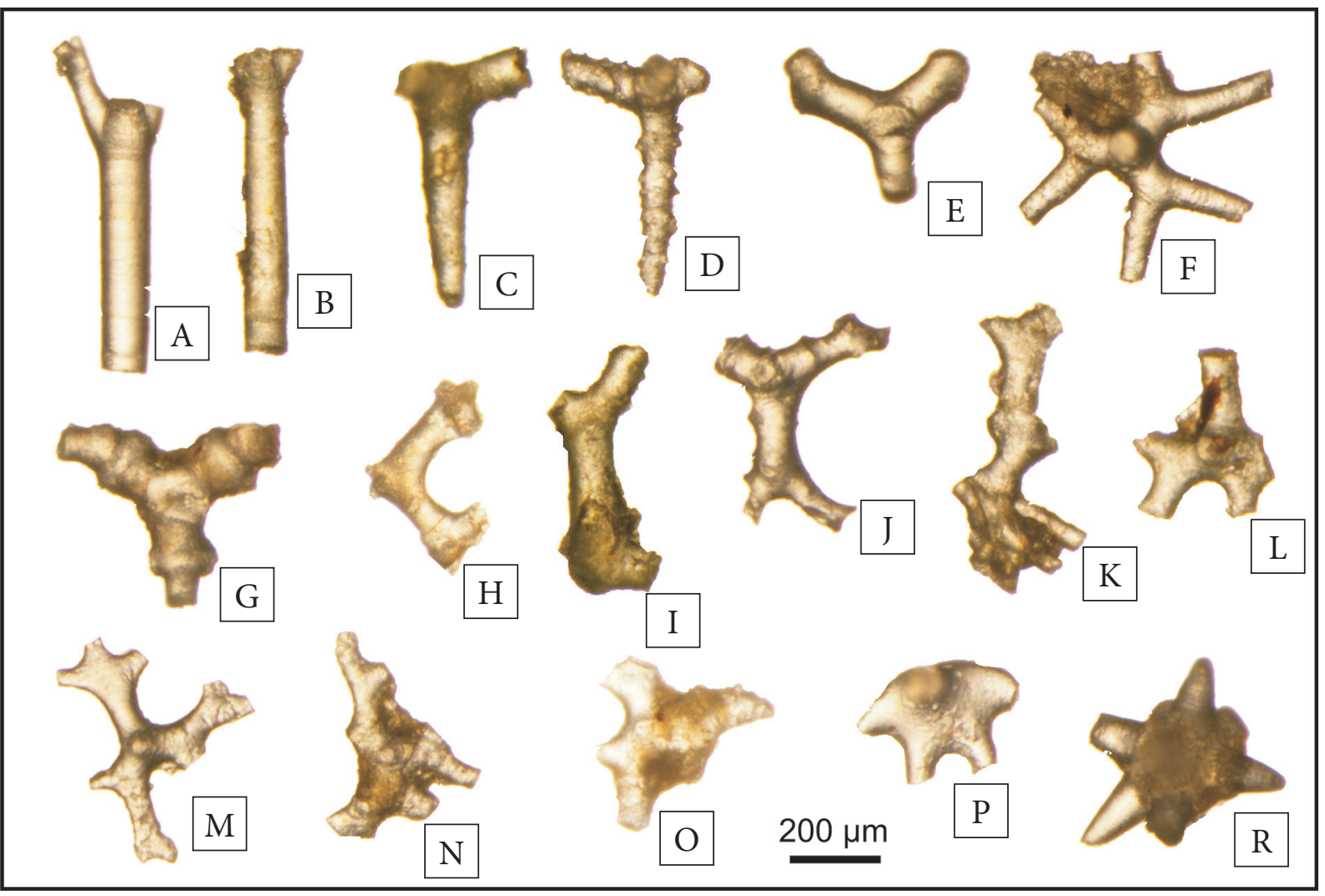

Fig. 9. Spicules of siliceous sponges from Turonian Variegated Shale in the Trzemeśnia section. Demosponge spicules: A) Prodichotriaene; B) Prodichotriaene or protriaene; C) strongly crushed form resembling Ortotriaene; D) Ortotriaene or calthrop, additionally ornamented; E) Tetractine; F) Prodichotriaene; G) Tetractine or incomplete criccalthrop; H), I) unidentified type of desmas; J) desmas, most probably rhizoclone-type; K) unidentified various types of desmas; L) strongly crushed, probably prodichotriaene spicule; $M$ ) incomplete phyllotriaene; N), O) unidentified types of desmas; $P$ ) incomplete triaene. Hexactinellid spicule: R) incomplete acanthopentactine or pentactine. $G, H, N, O$ - sample Trz73; A, E, F, J, M, P-sample Trz-75; D, K-sample Trz82; L-sample Trz87; B, C, I-sample Trz97

The second subtype of sponge spicules comprises the selenasters and similar to them, but very rare, oxyspherasters. The first group is common in the studied assemblages. They are smooth on the surface and have a bean-shape. Their size is between $0.12-0.17 \mathrm{~mm}$. Oxyspherasters are commonly larger (up to $0.18 \mathrm{~mm}$ ), and the main difference between them is the number of "spines" extending from the spherical inner part of the spicule. The content of both subtypes in the assemblage is $22 \%$.

The third subtype of sponge spicules comprises the desmas, which are generally irregular. Their shape is differentiated and commonly possesses root-like outgrowths, called clones. The geometry of desmas is multiaxial. In the studied assemblages, tetraclones predominate, and rhyzoclones are frequent. The content of desmas in the whole assemblage is $16 \%$.
The other morphotypes of sponge spicules, are rare triaxons, pentactines and hexactines, comprising of up to $3 \%$ of the whole spicule assemblages.

Additionally, monaxones (oxea or style) were occasionally found in the material studied. They are usually well-preserved as long and thick spicules. Monaxones are straight or tightened in the two ends (oxeasters), or only at one end (thylostyle). These spicules were not taking into account because this type can be present in different sponge groups, and does not have any significance in the sponge classification.

\section{Preservation state of spicules}

Spicules founded in the samples residuum, are strongly crushed. They are usually in pieces of $0.3-0.5 \mathrm{~mm}$ long. Only various types of monaxones are longer, better preserved, and usually complete. In the thin section view, spicules are 
predominantly recrystallized from primordial amorphous opal-A into more stable silica phase. In most of the visible cross-sections, spicule interior consists of two parts. The central part (remnants of central canal) is filled in by microcrystalline quartz (Fig. 5D), and the internal part is composed of microcrystalline, fibrous, radially arranged quartz. Some spicules are filled in by botryoidal cement, indicating a secondary precipitation of silica (Fig. 4F).

\section{DISCUSSION}

Spicules of sponges are present only in redeposited intervals of turbidite layers in the Variegated Shale. They are present mostly in silt and sand fractions of the sediments. It indicates that spicules were derived from the shallower part of the basin and redeposited during the sedimentation of the turbidity currents. The same mechanism was interpreted for the preceding sediments which belong to the Middle Lgota Beds, Mikuszowice Cherts and the Barnasiówka Radiolarian Shale Formation (e.g. M. Bąk et al. 2011).

The composition of spicules in the Turonian Variegated Shale is similar to those described from the Cenomanian formations (compare M. Bąk et al. 2011). Both in the Turonian and Cenomanian turbiditic sediments, morphotypes of lithistid spicules prevail over the hexactinellids, forming the main biogenic components.

\section{Palaeoenvironmental interpretations}

The deposition of the Turonian Variegated Shale took place in a deep sea basin, below the calcium compensation depth, as was interpreted by K. Bąk (2007a) using the analyses of microfossil composition from hemipelagic claystones. These sediments are devoid of calcareous benthic foraminifers. Among the planktonic microfossils, the only radiolarian tests are preserved in hemipelagic layers of this succession.

There are three possibilities of an interpretation of the occurrence of redeposited sponge spicules in the deep-water Silesian Basin during the Turonian times. The first of them is that spicules were redeposited directly from sponge buildups living on shelves, nearly simultaneously with turbidite sedimentation. The second possible interpretation is that spicules were derived from exhumed sponge build-ups, which grew during the Albian-Cenomanian times on shelves and were destroyed during the latest Cenomanian oceanic anoxic event (OAE2). The third one is that the sponge spicules were derived from loose material accumulated earlier in various parts of the basin slopes from which they were again redeposited due to turbidity currents and enhanced deep-water circulation during the Turonian times.

It seems that the third interpretation is most possible. A lower amount of spicules (usually less than 50\%) in the redeposited sediments of the Variegated Shale, in comparison to the amount of spicules in the Middle-Upper Cenomanian turbidites (even up to 90\%; M. Bąk et al. 2011) belong to the important factors. Another factor pointing to this interpretation is a very poor preservation state of spicules (crushed and broken singular spicules and secondary recrystallized spicules) in the Variegated Shale that may suggest their long and multiple redepositions. The third element of such interpretation is related to lack of calcareous benthic foraminifers which co-occur with sponge spicules in the Cenomanian turbidites, as numerous redeposited biogenic particles (M. Bąk et al. 2005, 2011, K. Bąk 2007a). The final element of the third interpretation is a fact that during the latest Cenomanian oceanic anoxic event (OAE2) through the earliest Turonian times, the sponge spicules have not been deposited in the Silesian Basin. Most probably the sponge buildups have been buried during that time. Their delivery into deep bottom renewed gradually after sedimentation of the second manganese layer in the Silesian Basin, i.e. during the earliest Turonian (M. Bąk et al. 2011). It was caused by a change in deep-water basin circulation after the OAE2 times. It was related, among others, to high sea level stand, the highest in the whole Cretaceous (e.g. Sahagian et al. 1996, Miller et al. 2005, Müller et al. 2008).

\section{CONCLUSIONS}

1. Turonian red, green and varicoloured claystone/mudstone layers dominate in the Variegated Shale of the western part of Silesian Nappe, Polish Outer Carpathians. They are 
intercalated with thin-bedded (up to $6 \mathrm{~cm}$ thick) siltstone - sandstone turbiditic layers, which contain spicules of sponges among the siliciclastic fine-grained material.

2. The siltstone-sandstone layers contain mainly quartz, glauconite, mica flakes, associated with sponge spicules and radiolarian skeletons. The highest amount of sponge spicules is $50 \%$. In the microscopic view, the claystone, siltstone-sandstone layers consist of several types of microfacies as: (1) quartz fine arenite and siltstone (2) quartz-glauconitic fine arenite and siltstone, (3), sublitharenite enriched in sponge spicules (4) spiculitic fine sublitharenite, (5) radiolarian-spiculitic packed biomicrite, (6) radiolarian sparse biomicrite, and (7) pellet sparse biomicrite. Sponge spicules dominate in the spiculitic sublitharenite microfacies.

3. Sponge spicules contains mostly forms, which belong to the Lithistida group ( $97 \%$ of morphotypes), with a small admixture of spicules from the Hexactinellidae group. The predominance of tetraclones among desmas, and the high-content of different types of triaenes, indicate the dominance of sponges from subfamily Tetracladina.

4. Three sponge spicule morphotypes dominate, including triaenes (59\%), selenasters (22\%) and desmas (16\%). The other morphotypes are triaxons, pentactines and hexactines, comprising up to $3 \%$ of the whole spicule assemblages. Additionally, monaxones (oxea or style) were occasionally found in the material studied.

5. The preservation state of spicules is generally poor. They are strongly crushed, and occur in pieces of $0.3-0.5 \mathrm{~mm}$ long; only monaxones are longer and better preserved. Spicules are predominantly recrystallized from primordial amorphous opal-A into more stable silica phase.

6. Most probably, the spicules of sponges in the Variegated Shale were derived from loose material accumulated earlier in various parts of the basin slopes, from which they were exhumed and again redeposited by turbidity currents during the Turonian times.
The authors are very grateful to Mike Kaminski for review and improving English of the manuscript, and to Jan Golonka for his editorial work.

This paper was supported by Funds of Pedagogical University of Cracow and AGH University of Science and Technology awarded to K. Bak and S. Okoński (DS-UP-WGB-3) and to M. Bąk (DSAGH WGGiOŚ-KGOiG no. 11.11.140.173).

\section{REFERENCES}

Alexandrowicz S.W., 1973. Gaize-type sediments in the Carpathian flysch. Neues Jahrbuch für Geologie und Paläontologie. Monatshefte Jg., Stuttgard H., 1, 1-17.

Bąk K., 2006. Sedimentological, geochemical and microfaunal responses to environmental changes around the Cenomanian-Turonian boundary in the Outer Carpathian Basin; a record from the Subsilesian Nappe, Poland. Palaeogeography, Palaeoecology, Palaeoclimatology, 237, 335-358.

Bąk K., 2007a. Deep-water facies succession around the Cenomanian-Turonian boundary in the Outer Carpathian Basin: sedimentary, biotic and chemical records in the Silesian Nappe, Poland. Palaeogeography, Palaeoecology, Palaeoclimatology, 248, 255-290.

Bąk K., 2007b. Changes in oxygenation of bottom sea water around the Cenomanian-Turonian boundary in marginal part of the Outer Carpathian Basin expressed by microfacies, microfossils and chemical records in the Skole Nappe (Poland). Annales Societatis Geologorum Poloniae, 77, 39-67.

Bąk K., 2007c. Organic-rich and manganese sedimentation during the Cenomanian-Turonian boundary event in the Outer Carpathian Basin, a new record from the Skole Nappe, Poland. Palaeogeography, Palaeoclimatology, Palaeoecology, 256, 21-46.

Bąk K., 2007d. Environmental changes during the Cenomanian-Turonian boundary event in the Outer Carpathian basins: a synthesis of data from various tectonicfacies units. Annales Societatis Geologorum Poloniae, 77, 171-191.

Bąk K., Bąk M. \& Paul Z., 2001. Barnasiówka Radiolarian Shale Formation - a new lithostratigraphic unit in the Upper Cenomanian-lowermost Turonian of the Polish Outer Carpathians (Silesian series). Annales Societatis Geologorum Poloniae, 71, 75-103.

Bąk M., 2000. Radiolaria from the Upper Cenomanian-Lower Turonian deposits of the Silesian Unit (Polish Flysch Carpathians). Geologica Carpathica, 51, 309-324.

Bąk M., 2011. Tethyan radiolarians at the CenomanianTuronian Anoxic Event from the Apennines (UmbriaMarche) and the Outer Carpathians: Palaeoecological and Palaeoenvironmental implications. [in:] Tyszka J. (ed.), Methods and Applications in Micropalaeontology. Part 2, Studia Geologica Polonica, 134, 1-279.

Bąk M., Bąk K. \& Ciurej A., 2005. Mid-Cretaceous spiculerich turbidites in Silesian Nappe of the Polish Outer Carpathians: radiolarian and foraminifera biostratigraphy. Geological Quarterly, 49, 275-290. 
Bąk M., Bąk K. \& Ciurej A., 2011. Palaeoenvironmental signal from the microfossils record in the Mikuszowice Cherts of the Silesian Nappe, Polish Outer Carpathians. [in:] Bąk M., Kaminski M.A. \& Waśkowska A. (eds), Integrating Microfossil Record from the Oceans and Epicontinetal Seas, Grzybowski Fundation Special Publication, 17, 15-25.

Bąk M., Waśkowska A., Ciurej A. \& Michalik M., 2013. Skały krzemionkowe okolic Myślenic jako prawdopodobny surowiec dla dawnych hut szkła. [Siliceous rocks in the area of Myślenice as the potentially occurring raw materials for the former glass-works]. Przegląd Górniczy, $69,3,17-23$.

Bieda F., Geroch S., Koszarski L., Książkiewicz M. \& Żytko K., 1963. Stratigraphie des Karpates externes polonaises. Biuletyn Instytutu Geologicznego, 181, 5-174.

Bryndal T., 2011. Identyfikacja małych zlewni podatnych na formowanie gwałtownych wezbrań na przykładzie Pogórza Dynowskiego, Strzyżowskiego i Przemyskiego. Przeglad Geograficzny, 83, 5-26. [with English summary].

Burtan J. (red.), 1964a. Szczegółowa mapa geologiczna Polski w skali 1:50 000 (bez utworów czwartorzędowych); Rejon Karpat i Przedgórza: arkusz Myślenice [Detailed Geological Map of Poland in scale 1:50,000 (without Quaternary sediments); the Carpathian and Fore-Carpathian area: Myślenice sheet]. Wydawnictwa Geologiczne, Warszawa.

Burtan J. (red.), 1964b. Szczegółowa mapa geologiczna Polski w skali 1:50 000 (bez utworów czwartorzędowych); Rejon Karpat i Przedgórza: arkusz Wisła [Detailed Geological Map of Poland in scale 1:50,000 (without Quaternary sediments); the Carpathian and Fore-Carpathian area: Wisła sheet]. Wydawnictwa Geologiczne, Warszawa.

Burtan J. (red.), 1964c. Szczegółowa mapa geologiczna Polski w skali 1:50 000 (bez utworów czwartorzędowych); Rejon Karpat i Przedgórza: arkusz Mszana Dolna [Detailed Geological Map of Poland in scale 1:50,000 (without Quaternary sediments); the Carpathian and Fore-Carpathian area: Mszana Dolna sheet]. Wydawnictwa Geologiczne, Warszawa.

Burtan J. \& Szymakowska F. (eds), 1964. Szczegółowa mapa geologiczna Polski w skali 1:50 000 (bez utworów czwartorzędowych); Rejon Karpat i Przedgórza: arkusz Osielec [Detailed Geological Map of Poland in scale 1:50,000 (without Quaternary sediments); the Carpathian and Fore-Carpathian area: Osielec sheet]. Wydawnictwa Geologiczne, Warszawa.

Csontos L. \& Vörös A., 2004. Mesozoic plate tectonic reconstruction of the Carpathian region. Palaeogeography, Palaeoecology, Palaeoclimatology, 210, 1-56.

De Laubenfels M.W. 1955. Archaeocyatha and Porifera. [in:] Moore R.C. (ed.), Treatise on Invertebrate Paleontology, E, 1-113.

Folk R.L., 1959. Practical petrographic classification of limestones. American Association of Petroleum Geologists Bulletin, 43, 1-38.

Folk R.L., 1962, Spectral subdivision of limestone types. [in:] Ham W.E. (ed.), Classification of carbonate rocks, American Association of Petroleum Geologists Memoir, $1,62-84$.
Folk R.L., 1974. Petrology of Sedimentary Rocks. Hemphill Publishing, Austin, TX.

Gasse W., Göecke R. \& Hilpert K.H., 1991. The hexactinellid sponge genus Becksia Schlüter, 1868 from the Campanian of the NW Münsterland (Upper Cretaceous, NW Germany). [in:] Reitner J. \& Keupp H. (eds), Fossil and Recent Sponges, Springer Verlag, Berlin, 21-35.

Golonka J., Oszczypko N. \& Ślączka A., 2000. Late Carboniferous-Neogene geodynamic evolution and palaeogeography of the circum-Carpathian region and adjacent areas. Annales Societatis Geologorum Poloniae, 70, 107-136.

Kauffman E.G., Herm D., Johnson C.C., Harries P. \& Efling R.H., 2000. The ecology of Cenomanian lithistid sponge frameworks, Regensburg area, Germany. Lethaia, 33, 214-235.

Książkiewicz M., 1936. La structure de la zone de Lanckorona. Bulletin de L'Academie Polonaise des Sciences, Série A, 299-314.

Książkiewicz M., 1956. Geology of the Northern Carpathians. Geologische Rundschau, 45, 396-411.

Książkiewicz M. (ed.), 1962. Geological Atlas of Poland; Stratigraphic and Facial Problems, vol. 13. Cretaceous and Older Paleogene in the Polish Outer Carpathians. Instytut Geologiczny, Wydawnictwa Geologiczne, Warszawa [20 maps, 20 pp. explanatory notes].

Książkiewicz M., 1975. Bathymetry of the Carpathian Flysch Basin. Acta Geologica Polonica, 25, 309-368.

Książkiewicz M., 1977. Hypothesis of plate tectonics and the origin of the Carpathians. Annales Societatis Geologorum Poloniae, 47, 329-353.

Miller K.G., Kominz M.A., Browning J.V., Wright J.D., Mountain G.S., Katz M.E., Sugarman P.J., Cramer B.S., Christie-Blick N. \& Pekar S.F., 2005. The Phanerozoic record of global sea-level change. Science, 310, 1293-1298.

Müller R.D., Sdrolias M., Gaina C., Steinberger B. \& Heine C., 2008. Long-term sea-level fluctuations driven by ocean basin dynamics. Science, 319, 1357-1362.

Nestler H., 1961. Spongien aus der weissen Schreibkreide (unt. Maastricht) der Insel Rügen (Ostsee). Paläontologische Abhandlungen, 1, 1-70.

Neuhuber S., Wagreich M., Wendler I. \& Spötl C., 2007. Turonian oceanic red beds in the Eastern Alps: Concepts for palaeoceanographic changes in the Mediterranean Tethys. Palaeogeography, Palaeoclimatology, Palaeoeco$\log y, 251,222-238$.

Okoński S., 2012. Analiza najstarszych pstrych głębokomorskich osadów basenu śląskiego Karpat Zewnętrznych (górna kreda) w oparciu o odsłonięcie na Grzbiecie Barnasiówki koło Myślenic. Instytut Geografii, Uniwersytet Pedagogiczny, Kraków [M.Sc. thesis].

Oszczypko N., 2004. The structural position and tectonosedimentary evolution of the Polish Outer Carpathians. Przeglad Geologiczny, 52, 780-791.

Oszczypko N., 2006. Late Jurassic-Miocene evolution of the Outer Carpathian fold-and thrust belt and its foredeep basin (Western Carpathians, Poland). Geological Quarterly, 50, 169-194.

Pettijohn F.J., Potter P.E. \& Siever R., 1972. Sand and sandstone. Springer-Verlag, New York. 
Pisera A., 1997. Upper Jurassic siliceous sponges from the Swabian Alb: taxonomy and paleoecology. Palaeontologia Polonica, 57, 1-214.

Reid R.E.H., 1962. Sponges and the Chalk Rock. Geological Magazine, 99, 273-278.

Sageman B.B., Meyers S.R. \& Arthur M.A., 2006. Orbital time scale and new $\mathrm{C}$-isotope record for Cenomanian-Turonian boundary stratotype. Geology, 34, 125-128.

Sahagian D., Pinous O., Olferiev A., Zakaharov V. \& Beisel A., 1996. Eustatic curve for the middle Jurassic-Cretaceous based on Russian platform and Siberian stratigraphy: Zonal resolution. American Association of Petroleum Geologists Bulletin, 80, 1433-1458.

Słomka T., 1995. Głębokomorska sedymentacja silikoklastyczna warstw godulskich Karpat [Deep-marine siliciclastic sedimentation of the Godula Beds, Carpathians]. Prace Geologiczne - Polska Akademia Nauk. Oddziat w Krakowie. Komisja Nauk Geologicznych, 139, 1-132 [with English summary].
Soest R.W.M. \& van Stentoft N., 1988. Barbados deep-water sponges. Studies on the Fauna of Curaçao and other $\mathrm{Ca}$ ribbean Islands, 70, 1-175.

Sujkowski Z., 1933. Niektóre spongiolity Tatr i Karpat [Sur certains spongiolithes de la Tatra et des Karpathes]. Sprawozdania - Państwowy Instytut Geologiczny, 7, 712-733 [with French summary].

Unrug R., 1959. Spostrzeżenia nad sedymentacją warstw lgockich [On the sedimentation of the Lgota beds]. Rocznik Polskiego Towarzystwa Geologicznego, 29, 197-225.

Unrug R., 1977. Ancient deep-sea traction currents deposits in the Lgota beds (Albian) of the Carpathian Flysch. Rocznik Polskiego Towarzystwa Geologicznego, 47, 355-370.

Wiedenmayer F., 1980. Siliceous sponges. Development trough time. [in:] Hartman W.D., Wendt J.W. \& Wiedenmayer F. (eds), Living and fossil sponges. Notes for a short course, Sedimenta, 8, 55-85.

Żytko K., 1999. Korelacja głównych strukturalnych jednostek Karpat Zachodnich i Wschodnich. Prace Państwowego Instytutu Geologicznego, 168, 135-164. 